\title{
Investigation of Shiga-like toxigenic Escherichia coli in meat products by quantitative PCR
}

\author{
Velebit Branko ${ }^{I}$ Lakićević Brankical, Borović Branka ${ }^{1}$,Janković Vesna ${ }^{1}$, Spirić Dankal, Baltić Tatjana ${ }^{1}$
}

A b s t r a c t: The aim of this study was to investigate and evaluate effectiveness of quantitative PCR (qPCR) in quantification of Shiga-like toxigenic E. coli (STEC) in artificially contaminated deli meat slices compared to plate count technique. Experiment was designed to investigate capability of qPCR using selected pair of primers amplifying rpoB household gene and serial decimal dilution of an overnight suspension of E. coli O157:H7 culture. Subsequently, slices of smoked pork loin were contaminated by respective decimally diluted dose of STEC. DNA was extracted from the samples and qPCR was run in triplicate. Mean Ct values of amplified rpoB gene were compared to each inoculum dose and standard curves were generated. Results clearly showed that the lowest detectable level of STEC in pork loin slices using qPCR was $6.8 \times 10^{1} \mathrm{CFU} / \mathrm{g}$. Further optimization of method should be done in order to resolve, if possible, discrepancies at the levels of contamination less than $100 \mathrm{CFU} / \mathrm{g}$.

Key words: $q P C R$, E. coli O157, quantification.

\section{Introduction}

Shiga-like toxigenic E. coli have emerged as important food-borne pathogens, causing hemorrhagic colitis, which is sporadically complicated by hemolytic uremic syndrome. Onset of the illness requires a very low dose of STEC, in between 10-700. Standard or validated alternative methods are available and are recommended to be used for the detection and isolation of STEC O157 from food and animals. For the other serotypes, there are no universally accepted and validated methods, but pragmatic approaches have been produced. Pathogenic E. coli strains can be divided into Enteropathogenic E. coli (EPEC) strains, which "only" cause A/E (attaching-and-effacing) lesions, Shiga-toxin producing E. coli (STEC) strains, which possess and express stx genes, and Enterohemorrhagic E. coli (EHEC), which constitute a subset of STEC as classical EHEC can cause both hemorrhagic colitis (HC; due to $\mathrm{AE}$ lesion) and hemolytic uremic syndrome (HUS; due to the Shiga toxins) (Bunčić, 2000). Different virulence genes, such as $s t x_{1}$ and $s t x_{2}$ and their variants, which encode Shiga toxins, eae, which encodes the bacterial outer-membrane protein intimin, nle, which encodes translocated substrates of the type III secretion system, ehxA, which encodes the EHEC hemolysin, iha, which encodes an adherenceassociated protein, esp $\mathrm{P}$, which encodes the serine protease, and $h l y \mathrm{~A}$, which encodes enterohemolysin, have been targeted to assess the presence of STEC (Coombes et al., 2008; Paton and Paton, 1998; Pradel et al., 2008).

Improved methods for the detection and isolation of STEC non-O157 from foods, animals and the environment should be developed and validated. There is no standard protocol for enumeration of STEC O157 or other STEC serotypes in food or environmental samples and such quantitative methods should be developed. Enumeration of STEC is generally not conducted as part of routine monitoring or testing programs, although quantitative data are essential to better understand the human health risks. Recent advances in molecular detection methods combine the traditional detection methods and target serotype specific genes, stx, as well as other virulence genes. However, isolation of STEC, and subsequent strain characterization is still needed in order to ensure that the detected genes are present on the same bacteria.

Acknowledgements: A part of this study was funded by the European Commission within the $6^{\text {th }}$ Framework Program (№ 007081) ,PathogenCombat: Control and prevention of emerging and future pathogens at cellular and molecular level throughout the food chain“.

${ }^{1}$ Institute of Meat Hygiene and Technology, Kaćanskog 13, 11040 Belgrade, Republic of Serbia.

Corresponding author: Velebit Branko, velebit@inmesbgd.com 
Microbial cross-contamination at production site is one of the major factors of contamination of foods with STEC. Good hygiene practices at the abattoirs and at processing plants, including monitoring for microbiological indicators (Enterobacteriaceae and in generic E. coli), is likely to be the most effective method for reducing the public health risks for STEC infection. However, compliance with the hygiene criteria does not necessarily guarantee the absence of STEC at concentrations sufficient to cause human disease. Application of efficient validated HACCP-procedures for production of raw ready-to-eat meat, meat preparations and other foods is important to reduce the public health risks for STEC infection (EFSA 2008).

Generally, the DNA amplification-based techniques are rapid and will give a result within hours. One of the advantages of DNA-based methods is that it is possible to simultaneously investigate cultures for several genes at the same time. However, when testing mixed cultures the detected genes might not originate from the same STEC strain. By using DNA-based methods it is also possible to differentiate between the different stx subtypes. Furthermore, several quantitative PCR methods can be used to assist in subculturing of selected enrichment broths with priority given to the highest target concentration since there is a correlation between the number of stx gene copies and the success of isolation of STEC from an enrichment broth. DNA based methods have the disadvantage of being unable to distinguish between DNA from viable and non-viable cells, although this may only be important in specific situations.

In the last 10 years, Real-Time PCR systems based on SYBR Green I and TaqMan technologies have increasingly been used for accurate and reliable detection and quantification of various foodborne pathogens (Rodriguez-Lázaro et al., 2004a; Rawsthorne and Phister, 2006; Skånseng et al., 2006; Malorny et al., 2007), including STEC in contaminated samples along the food production chain. Compared to conventional PCR-based methods, Real-Time PCR technologies involve a lower risk of cross-contamination because the presence of the target sequence(s) in the sample is indicated by an increase in fluorescence signal, and no post-PCR processing of the sample is required (Rodríguez-Lázaro et al., 2004c; Rossmanith et al., 2006; Cocolin and Rantsiou, 2007).

\section{Materials and methods}

E. coli O157:H7 ATCC 35150 strain was used for assessing Real Time PCR efficiency, optimization of amplification conditions and inoculation of pork loin slices.

BHI broth (Oxoid, UK) was used for cultivation of strain preceding DNA extraction and for inoculation of dry pork loin slices. MRD (Merck, Germany) was used for preparation of serial dilutions. ChromID O157:H7 agar (Biomerieux, France) was used for quantification of $E$. coli $\mathrm{O} 157: \mathrm{H} 7$ in both overnight $(\mathrm{o} / \mathrm{n})$ culture broth and in inoculated samples. The final concentration of cells in the meat product ranged from $10^{8}$ to $10^{1} \mathrm{CFU} / \mathrm{g}$.

\section{Extraction of DNA from cultures and inoculated samples}

One $\mathrm{mL}$ of an $\mathrm{o} / \mathrm{n}$ culture was centrifuged at $13.000 \mathrm{rpm}$ for $5 \mathrm{~min}$ at $4^{\circ} \mathrm{C}$ and resuspended in $100 \mu 1$ of PrepMan Ultra reagent (Applied Biosystems, Foster City CA, USA) placed in a $1.5 \mathrm{~mL} \mathrm{mi-}$ cro centrifuge tube. The samples were heated in boiling water for 10 minutes, allowed to cool to room temperature and centrifuged at $13.000 \mathrm{rpm}$ for 2 min. The supernatant (containing the DNA) was transferred to a clean $1.5 \mathrm{~mL}$ micro centrifuge tube. DNA was quantified by using the UV Biophotometer instrument (Eppendorf, Germany) and diluted to a final concentration of $100 \mathrm{ng} / \mu \mathrm{L}$.

For loin slices, $10 \mathrm{~g}$ of sample was diluted in $90 \mathrm{ml}$ of Maximum Recovery Diluent (MRD) in a stomacher bag and homogenized in a stomacher machine (AES Chemunex, France) for $1 \mathrm{~min}$. The debris was left to deposit for about $5 \mathrm{~min}$. One $\mathrm{mL}$ of homogenate was transferred to a $1.5 \mathrm{ml}$ sterile tube

Table 1. List of primers used in experiment

Tabela 1. Spisak prajmera koji su korišćeni u ogledu

\begin{tabular}{llc}
\hline $\begin{array}{l}\text { Primer name/ } \\
\text { Ime prajmera }\end{array}$ & Sequence $\left(5^{\prime}-3^{\prime}\right)$ & $\begin{array}{c}\text { Amplified product size/ } \\
\text { Veličina amplifikovanog proizvoda }\end{array}$ \\
\hline rpoB-F & GGTAGTGAATTTCGTCAGTTACA & $130 \mathrm{bp}$ \\
rpoB-R & GTATGTCCAATCGAAACCCCT & \\
\hline
\end{tabular}


and centrifuged at $13.000 \mathrm{rpm}$ for $5 \mathrm{~min}$. The extraction was further carried as described above.

The oligonucleotides used as PCR primers are shown in Table 1. These amplified a region of $r p o B$ housekeeping gene encoding RNA polymerase $\beta$ subunit.

\section{Amplification conditions}

Real Time PCR amplification was performed using a Brilliance III SYBR Green Real Time PCR kit (Agilent, USA) in a total volume of $20 \mu \mathrm{L}$ containing $10 \mu \mathrm{L}$ of $2 \times$ reaction buffer, $1 \mu \mathrm{L}$ of each primers, $1 \mu \mathrm{L}$ of template DNA and $7 \mu \mathrm{L}$ of PCR water to make up the final volume. Amplification was performed using an Agilent MX3005P thermo cycler (Agilent Technologies, USA). Thermal cycling conditions was as follows: initial denaturation at $95^{\circ} \mathrm{C}$ for $5 \mathrm{~min}$, followed by 40 cycles of $95^{\circ} \mathrm{C}$ for $10 \mathrm{~s}$ and $60^{\circ} \mathrm{C}$ for $20 \mathrm{~s}$.

\section{Enumeration}

An overnight culture of $E$. coli $\mathrm{O} 157: \mathrm{H} 7$ used to contaminate the sliced pork loin was enumerated on ChromID O157:H7 agar to determine the exact count of colony forming unit (CFU) inoculated in the samples. The signals obtained (threshold cycle, $\mathrm{Ct}$ ) for the serial dilutions of E. coli $\mathrm{O} 157: \mathrm{H} 7$ in MRD and in pork loin were plotted against the $\log _{10} \mathrm{CFU} / \mathrm{mL}$ or $\mathrm{CFU} / \mathrm{g}$ to construct the calibration curves. Determination coefficients $\left(\mathrm{R}^{2}\right)$ and amplification efficiency (AE) were calculated as described previously by Higuchi et al. (1993). Due to plating of $0.1 \mathrm{~mL}$ volume of each dilution the samples inoculated by $<10 \mathrm{CFU} / \mathrm{mL}$ were not detectable.

\section{Results and discussion}

When cells were diluted in MRD (Figure 1.), the linearity range was from $8.78 \log _{10} \mathrm{CFU} / \mathrm{mL}$ to $1.78 \log _{10} \mathrm{CFU} / \mathrm{mL}$, covering 7 orders of magnitude. The efficiency was $99.25 \%$ and the correlation coefficient $\left(\mathrm{R}^{2}\right)$ was 0.959 .

Due to design of experiment, results of 5 levels of inoculation of sliced pork loins with serially diluted E. coli $\mathrm{O} 157: \mathrm{H} 7$ cells are displayed (Figure 2). The efficiency in this case was $101.35 \%$ and the correlation coefficient $\left(\mathrm{R}^{2}\right)$ was 0.972 .

Results showed that it was possible to quantify count of E. coli O157:H7 in MRD using standard curve down to the level of less than $100 \mathrm{CFU} / \mathrm{mL}$, more precisely at about $60 \mathrm{CFU} / \mathrm{mL}$. At lower dilution levels (from 1 to $10 \mathrm{CFU} / \mathrm{mL}$ ) $\mathrm{Ct}$ signals couldn't be detected. Moreover, even at the 10 -fold higher level, discrepancies of the Ct signals were noticed (data not shown) which could be attributed to the very small amount of initial DNA, non-homogenous distribution of bacteria in samples, or variable amplification efficiency during the first several cycles. Regarding quantification of $E$. coli $\mathrm{O} 157: \mathrm{H} 7$ in sliced smoked pork loin, we determined that

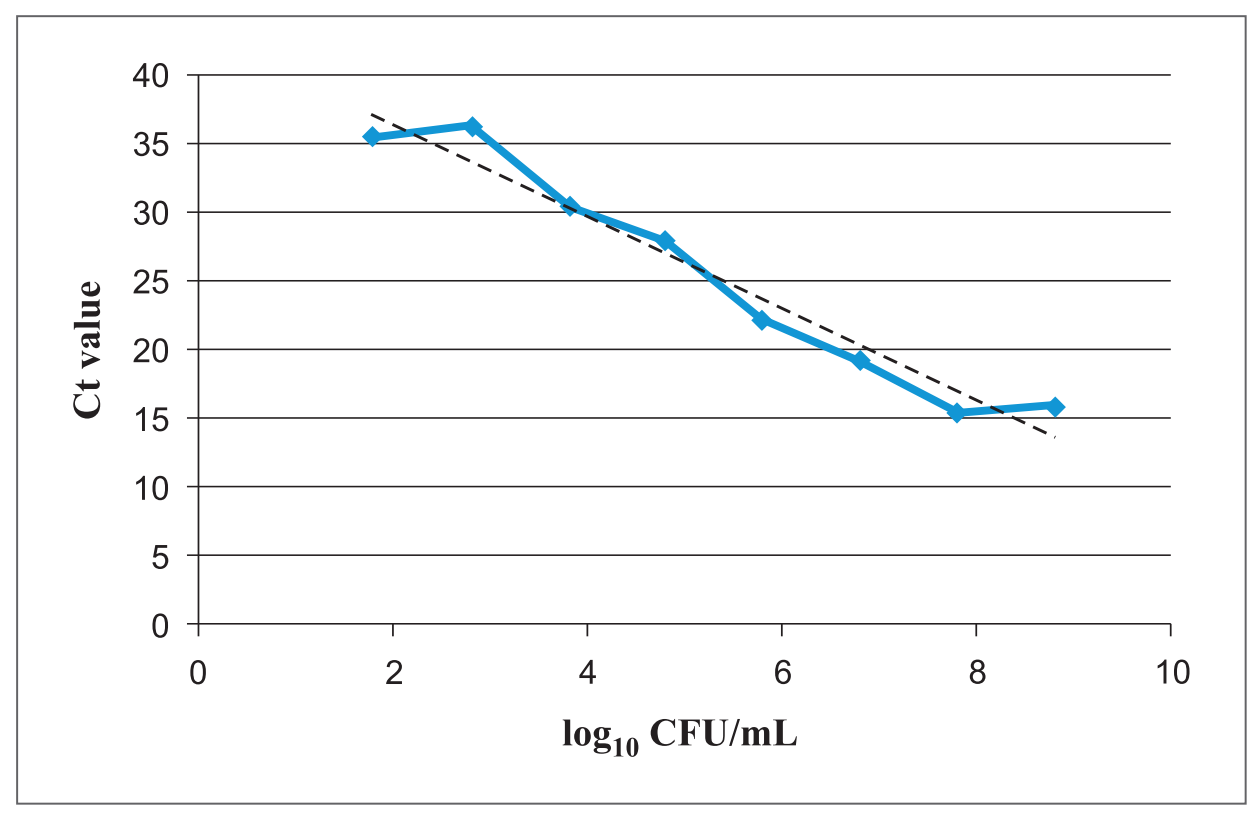

Figure 1. DNA standard curve of E. coli O157:H7; decimal dilutions in MRD

Slika 1. Standardna prava DNK E. coli O157:H7; decimalna razblaženja u MRD 


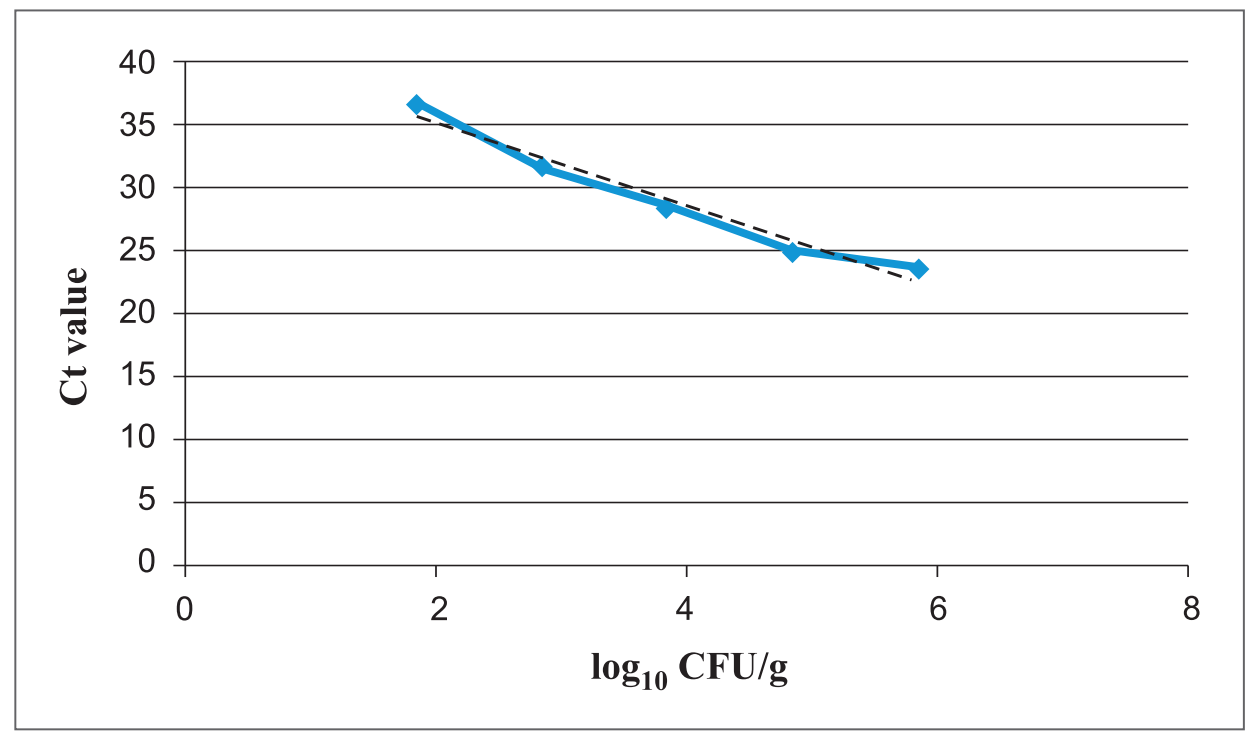

Figure 2. DNA standard curve of E. coli O157:H7 decimal dilutions in slices of smoked pork loin Slika 2. Standardna prava DNK E. coli O157:H7; decimalna razblaženja u uzorcima svinjske dimljene pečenice

absolute limit of quantification using standard curve was at approximately $70 \mathrm{CFU} / \mathrm{g}$. However, this data should be taken with great care since choice of kit for DNA, possible carryover of impurities or inhibitors, presence of aggregated cells etc., can have a significant effect on quantification results and could lead to misinterpretation.

In our experience which derived from repeated experiments of this type, safety margin $(95 \% \mathrm{CI})$ in terms of LOQ of E. coli O157:H7 in this type of meat product should be in range 100-300 CFU/g.

For the DNA standard curves, the efficiencies were different based on the matrix used, however the $\mathrm{R}^{2}$ value was always acceptable $(\geq 0.930)$.

Regarding alternative protocols of quantification of food-borne pathogens, Fukushima et al. (2007) proposed a buoyant density gradient centrifugation as concentration method for 12 food-borne pathogens. The detection limit of the protocol varied from $10-10^{3} \mathrm{CFU} / \mathrm{g}$, presenting favorable applicability for Salmonella spp. and C. jejuni, for which the detection of $10-10^{2} \mathrm{CFU} / \mathrm{g}$ in naturally contaminated chicken was obtained in 3 hours.

However, the results in terms of quantification limit obtained here are in agreement with the reports of other authors who developed qPCR protocols to quantify L. monocytogenes in meat (RodriguezLázaro et al., 2004) and in salmon products (Rodriguez-Lázaro et al., 2005).

\section{Conclusion}

In this study, we evaluated efficiency of Real-Time PCR quantitative methods against the Plate Count technique for quantification of decimal dilution series of STEC in deli meat matrix. The Real-Time PCR methods showed similar accuracy for quantitative detection of examined samples, but the sensitivity of Plate Count Technique was $1-2 \operatorname{logs}$ lower than the investigated molecular assays. According to the obtained results and with respect to the advantages of the molecular systems, this assay could be considered as a potential alternative to traditional cultural methods used for quantification of food borne pathogens in different foods and culture media matrixes. Care should be taken when calculating counts in the "risky" range of values obtained by using the standard curve, i.e. $100-1000 \mathrm{CFU} / \mathrm{g}$ or $\mathrm{mL}$ and further studies should be carried out in order to optimize protocol and performance characteristics. 


\section{References}

Barak J. D., Sananikone K., Delwiche M. J., 2005. Comparison of primers for the detection of pathogenic Eschericia coli using Real Time PCR. Letters in Applied Microbiology, 41,112-118.

Bunčić O., 2000. E. coli O157:H: karakteristike, mogućnosti razmnožavanja u mesu i kontrola. Tehnologija mesa, 50, $1-3,31-38$.

Cocolin L., Rantsiou K., 2007. Rapid methods for detection and prediction of the occurrence and virulence of pathogens in meat and meat producrs. Meat Technology, 48, $1-2,116-122$.

Coombes B. K., Wickham M. E., Mascarenhas M., Gruenheid S., Finlay B. B., Karmali M. A., 2008. Molecular analysis as an aid to assess the public health risk of nonO157 Shiga toxin-producing Escherichia coli strains. Applied and Environmental Microbiology 74, 2153-2160.

EFSA, 2010. The Community Summary Report on trends and sources of zoonoses and zoonotic agents and food-borne outbreaks in the European Union in 2008. The EFSA Journal 2010, 4196.

Fukushima H., Katsube K., Hata Y., Kishi R., Fujiwara S., 2007. Rapid separation and concentration of food-borne pathogens in food samples prior to quantification by viable-cell counting and real-time PCR. Applied and Environmental Microbiology 73, 92-100.

Higuchi R., Fockler C., Dollinger G., Watson R., 1993. Kinetic PCR analysis: real-time monitoring of DNA amplification reactions. Bio/Technology 11, 1026-1035.

Law D., 2000. Virulence factors of Escherichia coli O157 and other Shiga toxin-producing E. coli. Journal of Applied Microbiolology, 88, 729-745.

Lekanne D., Fijnvandraat R. H., Ruijter A. C., Moorman A. F., 2002. Sensitivity and accuracy of quantitative Real-Time polymerase chain relation using sybr green I depends on cDNA synthesis conditions. Analitical Biochemistry, 307, 63-69.

Malorny B., Bunge C., Helmuth R., 2007. A real-time PCR for the detection of Salmonella Enteritidis in poultry meat and consumption eggs. Journal of Microbiolology Methods, 70, 245-251.

Ostroff S. M., Tarr P. I., Neill M. A., Lewis J. H., HargrettBean N., Kobayashi J. M., 1989. Toxin genotypes and plasmid profiles as determinants of systemic sequelae in Escherichia coli O157:H7 infections. The Journal of Infection Diseases, 160, 994-998.

Oswald E., Schmidt H., Morabito S., Karch H., Marchés O., Caprioli A., 2000. Typing of intimin genes in human and animal enterohaemorrhagic and enteropathogenic Escherichia coli: characterization of a new intimin variant. Infect Immunology Journal, 68, 64 .
Paton J. C., Paton A. W., 1998. Pathogenesis and diagnosis of Shiga toxin-producing Escherichia coli infections. Clinical Microbiology Reviews 11, 450-479.

Pradel N., Bertin Y., Martin C., Livrelli V., 2008. Molecular analysis of Shiga toxin-producing Escherichia coli strains isolated from hemolytic-uremic syndrome patients and dairy samples in France. Applied and Environmental Microbiology 74, 2118-2128.

Rantsiou K., Alessandria V., Urso R., Dolci P., Cocolin L., 2008. Detection, quantification and vitality of Listeria monocytogenes in food as determined by quantitative PCR. International Journal of Food Microbiology, 121, 99-105.

Rawsthorne H., Phister T.G., 2006. A real-time PCR assay for the enumeration and detection of Zygosaccharomyces bailii from wine and fruit juices. International Journal of Food Microbiology, 112, 1-7.

Riley L. W., Remis R. S., Helgerson S. D., McGee H. B., Wells J. G., Davis B. R., Hebert E.S., Olcott R. J., Johnson L. M., Hargrett N. T., Blake P. A., Cohen M. L., 1989. Hemorrhagic colitis associated with a rare Escherichia coli serotype. The New England Journal of Medicine, 308, 681-685.

Rodriguez-Lázaro D., Jofré A., Aymerich T., Hugas M., Pla M., 2004. Rapid quantitative detection of Listeria monocytogenes in meat products by realtime PCR. Applied and Environmental Microbiology 70, 6299-6301.

Rodriguez-Lázaro D., Jofré A., Aymerich T., Garriga M., Pla M., 2005. Rapid quantitative detection of Listeria monocytogenes in salmon products: evaluation of prereal-time PCR strategies. Journal of Food Protection 68, $1467-1471$.

Rodriguez-Lázaro D., Hernandez M., 2006. Isolation of Listeria monocytogenes DNA from meat products for quantitative detection by real-time PCR. Journal of Rapid Methods and Automation in Microbiology 14, 395-404.

Rossen L., Norskov P., Holmstrom K., Rasmussen O. F., 1992. Inhibition of PCR by components of food samples, microbial diagnostic assays and DNA extraction solutions. International Journal of Food Microbiology 17, $37-45$.

Rossmanith P., Krassnig M., Wagner M., Hein I., 2006). Detection of Listeria monocytogenes in food using a combined enrichment/real-time PCR method targeting the prfA gene. Research in Microbiology 157, 763-771.

Skånseng B., Kaldhusdal M., Rudi K., 2006. Comparison of chicken gut colonisation by the pathogens Campylobacter jejuni and Clostridium perfringens by real-time quantitative PCR. Molecular and Celluar Probes, 20, 269-279. 


\title{
Ispitivanje Shiga-like toksigenih Escherichia coli u proizvodima od mesa pomoću kvantitativnog PCR-a
}

\author{
Velebit Branko, Lakićević Brankica, Borović Branka, Janković Vesna, Spirić Danka, Baltić Tatjana
}

$R$ e z i m e : Cilj ovog rada bio je da se ispita, uporedi i oceni efikasnost kvantitativnog PCR-a u kvantifikaciji Shiga-like toksigenih E. coli (STEC) u eksperimentalno kontaminiranim narescima proizvoda od mesa u odnosu na klasičnu tehniku brojanja kolonija. Ogled je osmišljen tako da se primarno ispitaju mogućnosti kvantitativnog PCR-a korišćenjem izabranog para prajmera koji amplifikuje deo rpoB ,household“ gena u ekstraktima DNK iz serijskih decimalnih razređenja prekonoćne suspenzije kulture E. coli O157:H7. Uzorci svinjske dimljene pečenice kontaminirani su odgovarajućim serijskim razređenjima STEC. Nakon što je ogled ponovljen tri puta, napravljena je standardna prava odnosa srednje Ct vrednosti amplifikacionog signala za gen rpoB i odgovarajućeg razređenja inokuluma. Dobijeni rezultati jasno ukazuju da je limit kvantifikacije STEC u veštački inokulisanoj pečenici koji se može detektovati kvantitativnim PCR-om 68 CFU/g. Neophodna je dalja optimizacija ove metode kako bi se uklonila neslaganja koja se često pojavljuju kod nivoa kontaminacije manjih od $100 \mathrm{CFU} / \mathrm{g}$.

Ključne reči: $q P C R$, E. coli O157, kvantifikacija.

Paper received: 16.09 .2013 .

Paper accepted: 18.09.2013. 